Indian J. Anim. Hlth. (2020), 59(2)-Special Issue: 13-26

DOI: $10.36062 /$ ijah.59.2SPL.2020.13-26

Invited Review Article

\title{
PROBIOTICS IN FINFISH AQUACULTURE: AN INDIAN PERSPECTIVE
}

\author{
M. I. R. KHAN ${ }^{1}$, T. G. CHOUDHURY ${ }^{1}$ AND D. KAMILYA ${ }^{1 *}$ \\ ${ }^{1}$ Department of Aquatic Health and Environment, College of Fisheries, Central Agricultural University, \\ Lembucherra -799 210, Tripura, India
}

\begin{abstract}
With the ever-expanding global population, there has been an increasing demand for fish and fishery products. To meet this ever-increasing demand for fish, aquaculture practices have been expanded and intensified over the decades. Intensive aquaculture practices cause stress to the reared animals, leading to increase susceptibility of the host to infectious diseases, which ultimately cause economic loss to the fish farming communities. Generally, antibiotics and chemotherapeutics are used to control infectious diseases in aquaculture. The use of probiotics is increasingly being recognized as an alternative to antimicrobial agents, as the development and emergence of drug and antibiotic resistance has become a growing concern. Probiotics are live microbial adjuncts that confer health benefits to the host. Besides enhancing the resistance of fish towards infectious diseases, probiotics also benefit the fish by promoting growth, stimulating immunity, providing nutrition, and improving the water quality of the rearing environment. This review aims to signify the necessity of using probiotic for sustainable aquaculture and to enlist the probiotic research in the recent past in India with their results on growth and health status of finfish.
\end{abstract}

Key words: Aquaculture, Growth, Immunity, India, Probiotics

\section{Introduction}

Aquaculture is one of the fastest-growing animal production sectors to cater the demands for protein-rich diet of today's growing population. Currently, the aquaculture sector contributes $46 \%$ of the total fish production, and the consumption of global food fish increased at an average annual rate of 3.1 percent from 1961 to 2017, a rate higher than that of all other animal protein foods, which increased by 2.1 percent per year (FAO, 2020). Over the years, diversification, expansion and intensification of aquaculture have taken place globally, to cater to the increasing demand of fish. With the increasing intensification and commercialization of aquaculture practice, diseases have become a major stumbling block in the fish farming industry. To tackle such significant concern, several vaccines are available; however, the solution may not be viable (due to protection against a single pathogen, availability, costefficacy, mass application) for farmers in developing country like India (Sommerset et al., 2005). Under such circumstances, the farmers are only left to treat diseases with a plethora of chemical additives and medicines, especially antibiotics (Huang et al., 2015).

However, there has been an increasing concern pertaining to the use of antimicrobial agents as a disease preventive measure due to the evolution of antimicrobial resistance among pathogenic bacteria (Balcázar et al., 2006). Many solutions have been suggested as an alternative, which includes natural immunostimulants, herbal 
extracts, antimicrobial peptides, bacteriophages, probiotics, prebiotics, synbiotics etc. Among all these novel approaches, probiotics have received particular interest owing to its efficacy in augmenting immune response, enhancing growth, natural availability, abundance and convenience in the application (Hoseinifar et al., 2018).

\section{What is a probiotic?}

The term 'probiotic' was coined by Lilly and Stillwell (1965) to designate unknown growthpromoting substances produced by ciliated protozoans. A joint working group of Food and Agriculture Organization of the United Nations (FAO) and World Health Organization (WHO) stated that probiotics are live microorganisms which, when administered in adequate amounts, confer a health benefit on the host (FAO/ WHO, 2001).

Probiotics have gradually gained popularity as an alternative to antimicrobial agents to promote growth and prevent diseases in aquaculture. Probiotics confer beneficial effects in the fish host when they are applied through the feed. Dietary administration of probiotics helps to modify the microbial balance of the gastrointestinal tract, stimulates the immune system, and provides nutritional benefits (Kesarcodi-Watson et al., 2008). Besides the health and growth promoting potentials, probiotics have an extended application in aquaculture. Given the intricate relationship between an aquatic animal and its surrounding environment, the concept of probiotic application in aquaculture has been broadened to include improvement of water quality by directly applying probiotics into the pond water. This extended application has been suggested to describe probiotics as microbial "water additives" (Moriarty, 1998). It is presumed that the bacteria which improve water quality may also improve the health status of the fish, and in fact, several commercial products, marketed as "probiotics", have sought to take advantage of this idea (Gatesoupe, 1999). In the last two decades, research and application of probiotics in aquaculture have expanded enormously. Recent findings have revealed that members from approximately 20 bacterial genera have been recognised as potential probiotic candidates, where the majority of potential species are represented by Bacillus spp. and lactic acid bacteria (LAB) group (Knipe et al., 2020).

\section{Mode of action of probiotics}

Although, probiotics have a generalised mode of action, they certainly play a vital role in the overall health responses of the host, particularly in immunological responses. In the recent past, intensive studies on probiotic characterization and application have shed light on the significance of probiotics, their mode of action, and led the future avenues for interdisciplinary work. Globally, researches have proposed several ways of action of probiotics, and the well-accepted modes of actions are presented in Fig. 1.

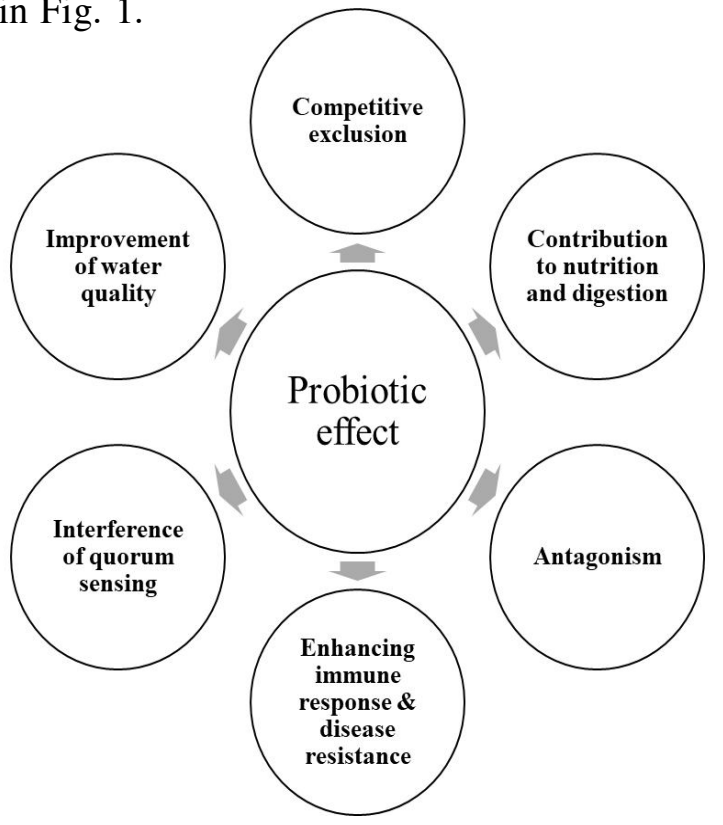

Fig. 1. Mode of action of probiotics

Competitive exclusion: Most of the pathogenic microbes require adherence site to mucosal surfaces of the host to initiate the disease 
development (Adams, 2010). Competitive exclusion is a phenomenon where a probiotic prevents or reduces the colonization of other bacteria such as pathogens, by competing for the site of adhesion, nutrition, etc. (Lara-Flores, 2011). For survival and proliferation of any microbial community, they require sufficient source of adhesion surface, nutrients, or energy (Verschuere et al., 2000). While struggling for basic needs for proliferation, colonized probiotics can out-compete the harmful pathogens by utilizing all the available resources. The colonization of probiotic bacteria leads to the production of certain antagonistic substances, which prevent the adhesion of any other challenging bacteria and ultimately eliminate its colonization (Verschuere et al., 2000). Although competition for adhesion sites has been suggested as a mode of action of probitiocs, there is little evidence in the literature to demonstrate the competetitive exclusion principle, particularly in the in vivo situation (Kesarcodi-Watson et al., 2008). In one study, a competitive exclusion effect was demonstrated by Vine et al. (2004), and they found that the attachment of the pathogen on the fish intestinal mucus was inhibited by the presence of probiotic bacteria.

Antagonism: Probiotics are responsible for the secretion of certain substances (e.g. bacteriocins) that may have a bactericidal or bacteriostatic effect on other harmful microbial populations (Verschuere et al., 2000). Antagonism of pathogens through probiotic may correspond to the production of various antimicrobial substances such as acetic acid, lactic acid, hydrogen peroxide, siderophores, lysozyme, short-chain fatty acids, etc. (Hoseinifar et al., 2017). Moreover, some probiotics may have the capacity to produce volatile fatty acid (butyric, acetic and propionic acid) and some organic acids, which results in reduced $\mathrm{pH}$ to inhibit the proliferation of opportunistic pathogens (Tinh et al., 2008). Antagonistic activity against pathogenic bacteria is probably the most studied mode of action of probiotics. In fact, the initial screening for potential probiotics essentially include in vitro (as well as in vivo) antagonism assays against different pathogens. A large number of published literatures have demonstrated antagonistic activity of potential aquaculture probiotics against a wide variety of fish pathogens (Balcázar et al., 2006; KesarcodiWatson et al., 2008).

Contribution to nutrition and digestive processes: Some probiotics are responsible for exerting a beneficial effect on the digestion of bio-molecules owing to their capacity to produce some extracellular enzymes, such as proteases, lipases, amylases and cellulase (Balcázar et al., 2006). Besides extracellular enzymes, probiotics have also been reported to secrete certain fatty acids, vitamins, essential amino acids, growth factors etc., which ultimately facilitate optimum feed utilization and enhance growth (Balcázar et al., 2006; Tinh et al., 2008; Lara-Flores and Aguirre-Guzman, 2009). For example, potential probiotics isolated from the intestine of Catla catla have been demonstrated to produce several extracellular enzymes including protease, amylase, lipase, cellulase, phytase and xylanase (Mukherjee and Ghosh, 2016).

Enhancement of the immune response and disease resistance: The probiotic application can lead to improve non-specific immune response (Balcázar et al., 2006). The administration of probiotic modulates the immunecompetence of aquatic animals by stimulating cellular and humoral responses (Biswas et al., 2013). The probiotic application promotes phagocytic response, production of cytokines, TNF- $\alpha$ (tumour necrosis factor $\alpha$ ), interleukins (IL-1 IL-6, IL-10, IL-12, IL-1 $\beta$ ), IFN- $\gamma$ (interferon gamma) and chemokines, along with the increased expression of certain immune component molecules, such as antibodies, lysozyme, complements, superoxide ion, acid phosphatase, serum proteins, and several 
antimicrobial peptides (Balcázar et al., 2007; Lara-Flores and Aguirre-Guzman, 2009; Mohapatra et al., 2012a,b; Das et al., 2013; Giri et al., 2013). All these probiotic attributes to the immuno-physiological response of the host ultimately correspond to elevated immune response and increased resistance against the pathogenic micro-organisms (Lakshmi et al., 2013). These immunomodulating responses by probiotic bacteria lead to the resistance of host against an array of pathogens, including Aeromonas spp., Edwardsiella sp., Photobacterium sp. Flavobacterium sp. and Vibrio spp. (Taoka et al., 2006). Additionally, several reports suggest that probiotics can also rouse the protective response against the viral (Chen et al., 2017), and fungal (e.g. Saprolegnia parasitica) pathogens (Atira et al., 2012).

Improvement of water quality: The application of probiotics maintains the optimum water quality parameters such as $\mathrm{pH}$, dissolved oxygen, ammonia, and hydrogen sulphide (AguirreGuzman et al., 2012). It was revealed that grampositive bacteria such as Bacillus spp. are more efficient in converting organic matter into $\mathrm{CO}_{2}$, slime, or bacterial biomass than the gramnegative bacteria (Chauhan and Singh, 2019). Moreover, during the production cycle, elevated levels of gram-positive bacteria (Bacillus spp.) can control the accumulation of dissolved and particulate organic carbon and facilitate improved water quality, survival, and growth rate (Balcázar et al., 2006). Several probiotics have been reported to have an algicidal property, thereby improving water quality (Fukami et al., 1997). Moreover, probiotic bacteria help in the bioremediation of ammonia and nitrite toxicity. Probiotics have also been related to the augmentation of beneficial microbes in the aquatic environment (Mohapatra et al., 2012a).

Interference of quorum sensing: Quorum sensing (QS) is a mechanism in which bacteria regulate various phenotypes such as biofilm formation, bioluminescence, virulence factors and swarming, and these have been shown to contribute to bacterial pathogenesis (Miller and Bassler, 2001). Since pathogenicity traits of bacteria are controlled by QS, disruption of QS (known as quorum quenching) has been suggested as a new anti-infective strategy to control pathogenic bacteria in the field of aquaculture and animal husbandry (Defoirdt et al., 2004; Boyen et al., 2009). In a recent research finding, bacteriocin from Bacillus sp. QSI-1 has been found to be an efficient quorum quencher and prevents biofilm formation of fish pathogen Aeromonas hydrophila (Chu et al., 2014). Some other probiotic bacteria, such as Lactobacillus and Bifidobacterium degrade the signal molecules of pathogenic bacteria by enzymatic secretion (Brown, 2011).

\section{Application of probiotic in Indian finfish aquaculture}

Intensive and semi-intensive farming practices in the Indian aquaculture sector have emerged as one of the most convenient and promising options to meet the nutritional requirements of a constantly increasing population. Furthermore, the involvement of modern approaches, such as the application of probiotics, has improved the overall capability and quality of production (Bandyopadhyay et al., 2015a,b). In recent time, most frequently used probiotic microorganisms in aquaculture belong to Bacillus spp., Lactobacillus spp., Bifidobacterium spp., Enterococcus spp., Streptomyces spp., Carnobacterium spp. and yeast (Van Doan et al., 2019). Numerous studies have been carried out to evaluate the effect of probiotics on fish growth, physiology, and health status (Bandyopadhyay and Mohapatra, 2009; Das et al., 2013; Giri et al., 2013; Gupta et al., 2014). Several studies have also been conducted in Indian finfish aquaculture with Bacillus spp. and Lactobacillus spp. being the most studied probiotic species. The effect of several probiotic strains on immunity, growth, haematological and biochemical responses of finfish is worthmentioning. A summary of the application of probiotics in finfish aquaculture of India is presented in Table 1. 
Probiotics in Indian aquaculture

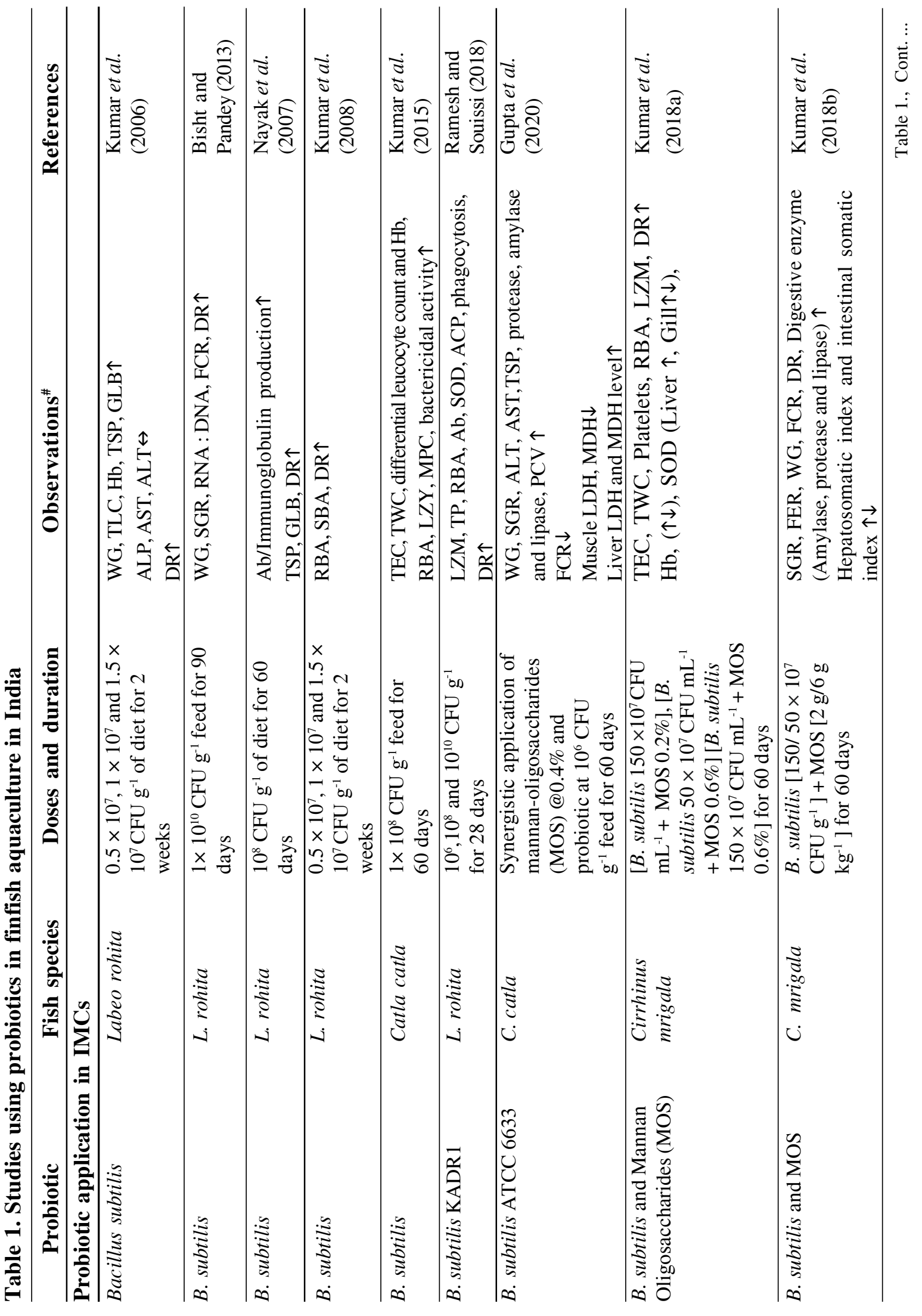




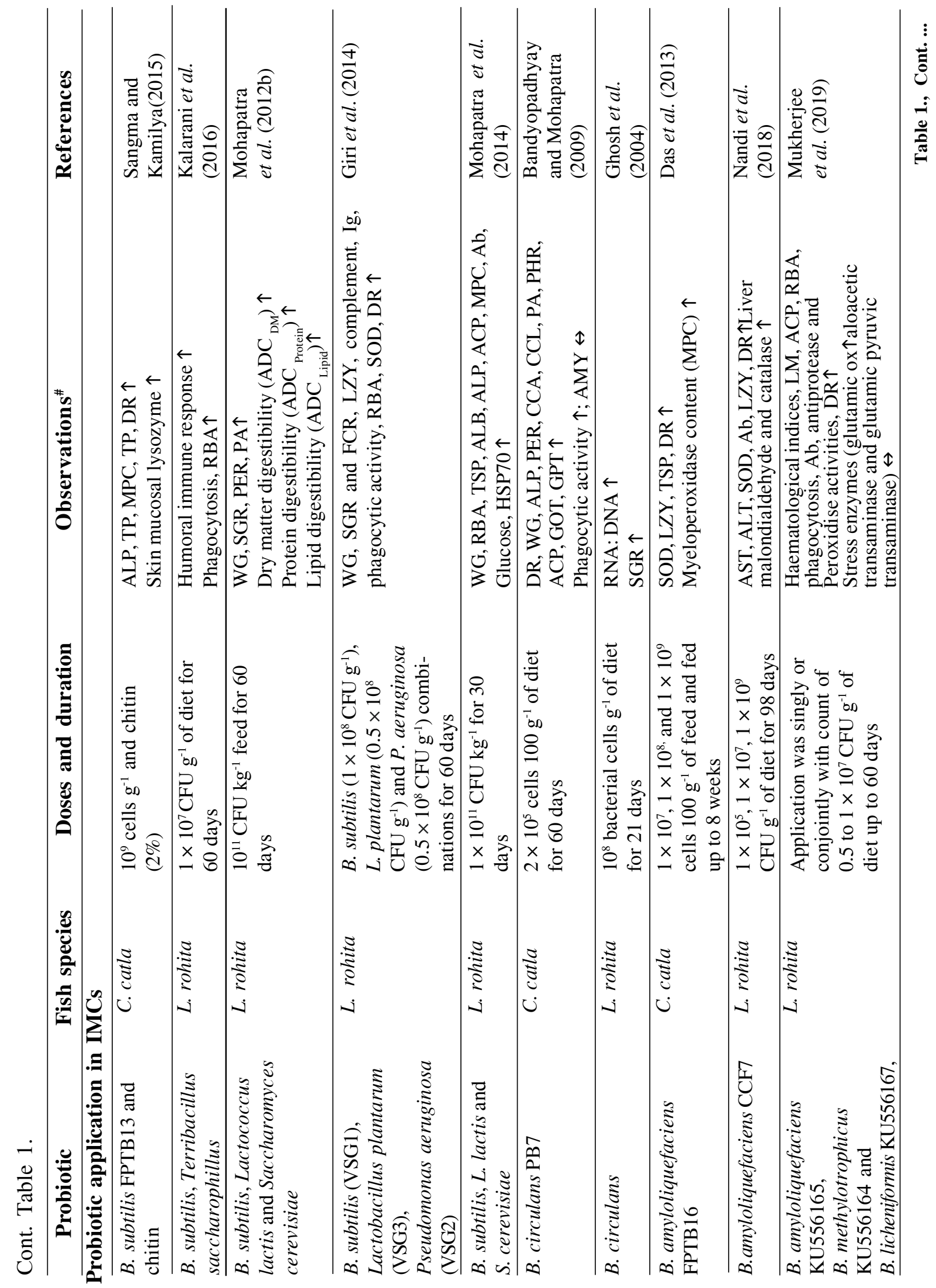


Probiotics in Indian aquaculture

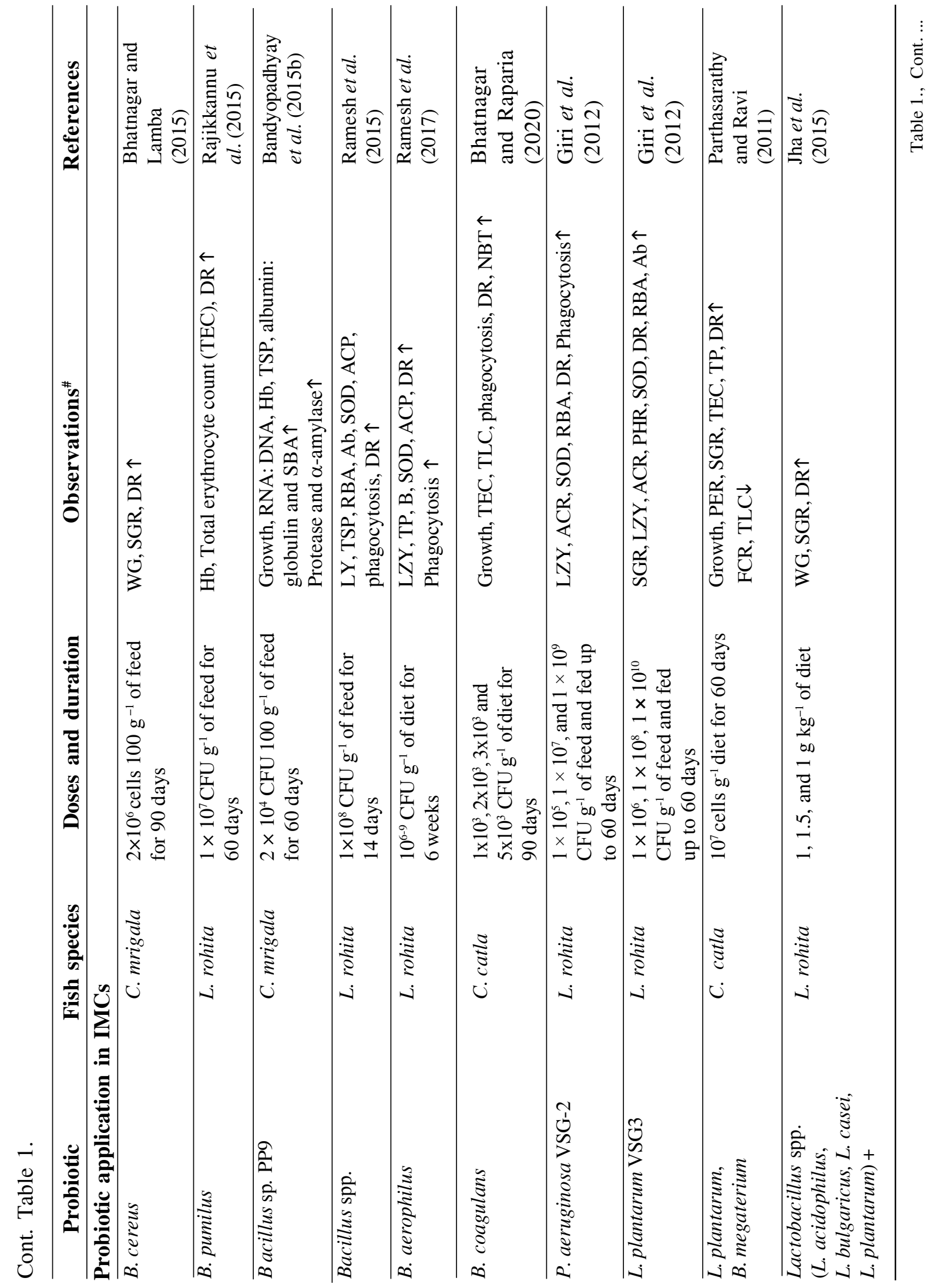




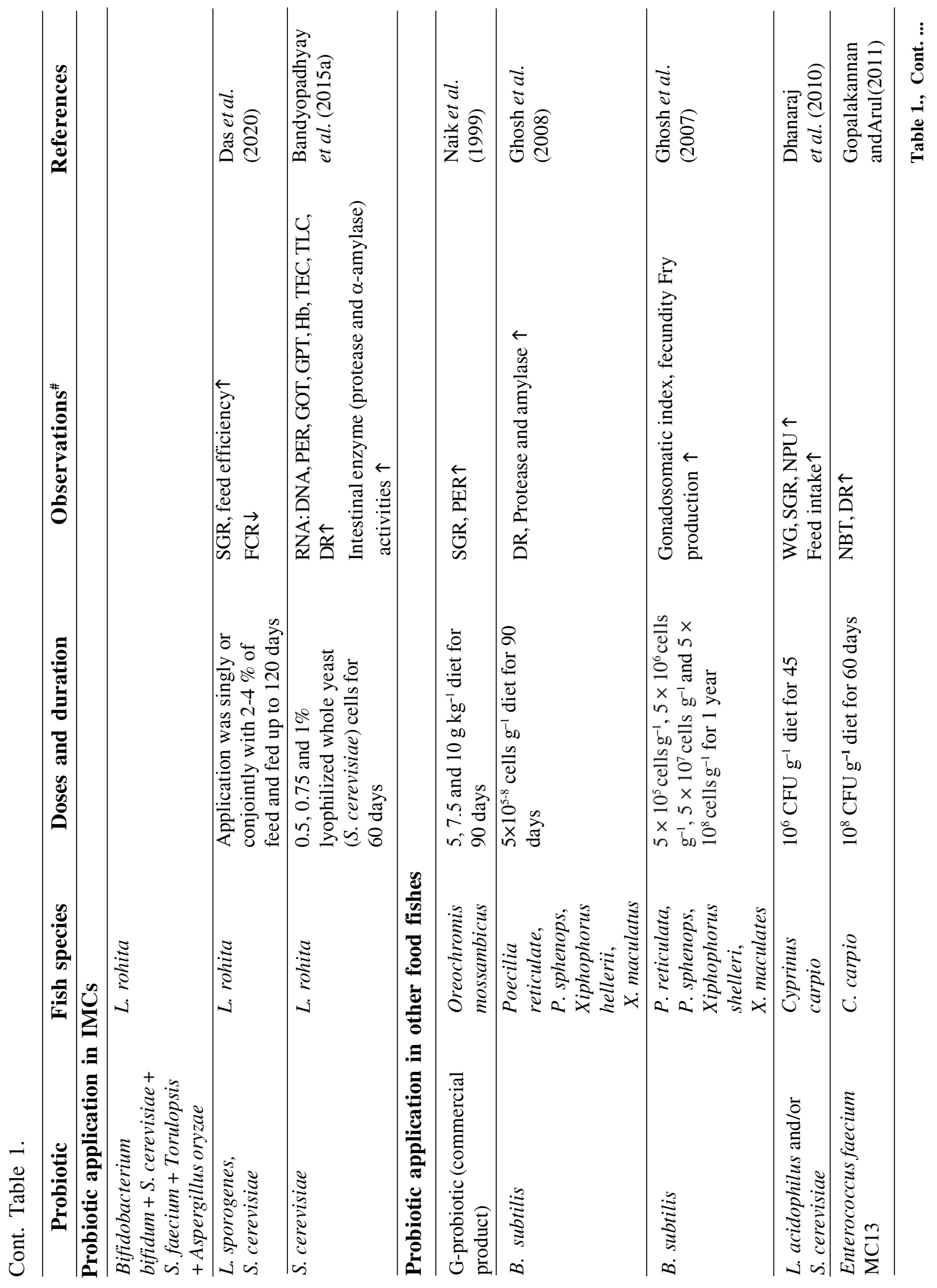


Probiotics in Indian aquaculture

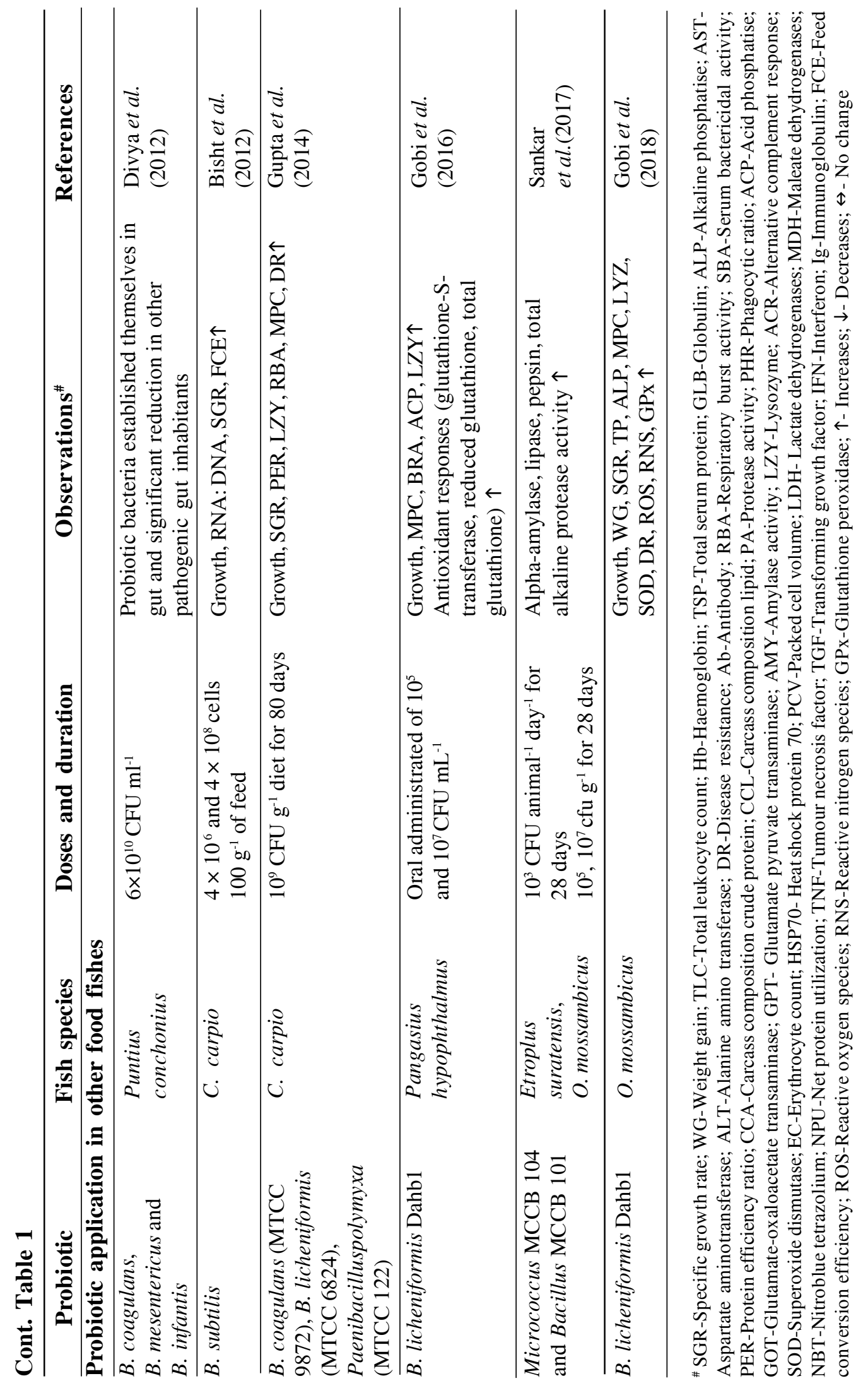




\section{Conclusions and future prospects}

In recent years, the application of probiotics as a biocontrol agent has improved overall aquaculture sector performance. Over the period, the isolation and characterisation of potential probiotic have leapt, and now efforts are required to streamline the entire range of probiotic strains and categorize them as per their specific action. After the sequential probiotic characterisation, the cutting-edge approaches should involve in designing the specific probiotic or cocktail of probiotics to target specific fish species to make them very efficient and economical. The determination of an optimal environment for probiotic interaction with their host and surrounding environment also holds a wide scope for further investigation. The fate of probiotic in host fish and time span for its efficacy in host organism are uncertain areas, which require further elaborated investigation.

Even after the great extent of work about the efficacy and mode of action of probiotics, there are still several uncertainties that require further clarification for advancing the probiotic application such as safety concerns, antibiotic resistance, production of enterotoxin, etc. Real-

\section{REFERENCE}

Adams CA, 2010. The probiotic paradox: live and dead cells are biological response modifiers. Nutr Res Rev, 23(1): 37-46, doi: 10.1017/ S0954422410000090

Aguirre-Guzman G, Lara-Flores M, Sanchez-Martinez JG, Campa- Cordova AI and Luna-Gonzalez A, 2012. The use of probiotics in aquatic organisms: A review. Afr J Microbiol Res, 6(23): 4845-4857, doi: $10.5897 / A J M R 11.1038$

Balcázar JL, de Blas I, Ruiz-Zarzuela I, Vendrell D, Calvo AC et al., 2007. Changes in intestinal microbiota and humoral immune response following probiotic administration in brown trout (Salmo trutta). Br J Nutr, 97(3): 522-527, doi: 10.1017/ S0007114507432986

Balcázar JL, Vendrell D, De Blas I, Cunninghem D, time evaluation of adherence and colonization of probiotic with the help of modern tools like hybridisation with green fluorescence protein (GFP) or some nontoxic radioactive compounds or fluorescence in situ hybridization (FISH) will be an interesting area to explore the relevance to probiotic research.Furthermore, interpretation with modern tools such as nextgeneration sequencing (NGS), genomics, transcriptomics, proteomics in the identification of unique genes and proteins associated with potential probiotics might reveal novel avenues for identification and application. Besides, the gnotobiotic approach can also be explored as they help in unveiling the function of beneficial symbionts on numerous biological processes of the host. Several synergistic strategies, such as application of immunostimulants, nondigestible fibres (prebiotics) etc. to enhance proliferation of gut microbiota, could be an area to explore. In conclusion, the possibilities are enormous, however systematic approaches alongside modern tools need to be undertaken to identify potential probiotics, which might offer novel possibilities to design the feasible future strategies in the health management of finfish aquaculture in India.

Vandrell D et al., 2006. The role of probiotic in aquaculture. Vet Microbiol, 114(3-4): 173-186, doi: 10.1016/j.vetmic.2006.01.009

Bandyopadhyay P and Mohapatra PKD, 2009. Effect of a probiotic bacterium Bacillus circulans PB7 in the formulated diets: on growth, nutritional quality and immunity of Catla catla (Ham.). Fish Physiol Biochem, 35: 467-478, doi: 10.1007/s10695-0089272-8

Bandyopadhyay P, Mishra S, Sarkar B, Swain SK, Pal A et al., 2015a. Dietary Saccharomyces cerevisiae boosts growth and immunity of IMC Labeo rohita (Ham.) juveniles. Indian J Microbiol, 55(1): 81-87, doi: 10.1007/s12088-014-0500-x

Bandyopadhyay P, Sarkar B, Mahanty A, Rathore RM and Patra BC, 2015b. Dietary administered Bacillus 
sp. PP9 enhances growth, nutrition and immunity in Cirrhinus mrigala (Hamilton). Proc Natl Acad Sci, India, Sect B Biol Sci, 85(3): 759-66, doi: 10.1007/s40011-015-0561-6

Bhatnagar A and Lamba R, 2015. Antimicrobial ability and growth promoting effects of feed supplemented with probiotic bacterium isolated from gut microflora of Cirrhinus mrigala. J Integr Agric, 14(3): 583-592, doi: 10.1016/S20953119(14)60836-4

Bhatnagar A and Raparia S, 2020. Evaluation of probiotic adequacy, immunomodulatory effects and dosage application of Bacillus coagulans in formulated feeds for Catla catla (Hamilton 1822). Int J Aquat Biol, 8(3): 194-208

Bisht A and Pandey N, 2013. Influence of probiotic administration, dominant gut bacterial strain Bacillus subtilis on growth performance of Labeo rohita (Hamilton) fingerlings. Int J Life Sci Biotechnol Pharma Res, 2 (3): 386-392

Bisht A, Singh UP and Pandey NN, 2012. Bacillus subtilis as a potent probiotic for enhancing growth in fingerlings of common carp (Cyprinus carpio L.). Indian J Fish, 59(3): 103-107

Biswas G, Korenaga H, Nagamine R, Takayama H, Kawahara S et al., 2013. Cytokine responses in the Japanese pufferfish (Takifugu rubripes) head kidney cells induced with heat-killed probiotics isolated from the Mongolian dairy products. Fish Shellfish Immunol, 34(5): 1170-1177, doi: 10.1016/ j.fsi.2013.01.024

Boyen F, Eeckhaut V, Van Immerseel F, Pasmans F, Ducatelle R et al., 2009. Quorum sensing in veterinary pathogens: mechanisms, clinical importance and future perspectives. Vet Microbiol, 135(3-4): 187-195, doi: 10.1016/ j.vetmic.2008.12.025

Brown M, 2011. Modes of action of probiotics: resent developments. J Anim Vet Adv, 10(14): 1895-1900, doi: 10.3923/javaa. 2011.1895. 1900

Chauhan A and Singh R, 2019. Probiotics in aquaculture: A promising emerging alternative approach. Symbiosis, 77(2): 99-113, doi: 10.1007/s13199018-0580-1

Chen BK, Dong Z, Liu DP, Yan YB, Pang NY et al., 2017. Iinfectious hypodermal and haematopoietic necrosis virus (IHHNV) infection in freshwater crayfish Procambarus clarkii. Aquaculture, 477: 76-79, doi: 10.1016/j.aquaculture.2017.05.002

Chu W, Zhou S, Zhu W and Zhuang X, 2014. Quorum quenching bacteria Bacillus sp. QSI-1 protect zebrafish (Danio rerio) from Aeromonas hydrophila infection. Sci Rep, 4: 5446, doi: 10.1038/srep05446

Das A, Nakhro K, Chowdhury S and Kamilya D, 2013. Effects of potential probiotic Bacillus amyloliquifaciens FPTB16 on systemic and cutaneous mucosal immune responses and disease resistance of catla (Catla catla). Fish Shellfish Immunol, 35: 1547-1553, doi: 10.1016/ j.fsi.2013.08.022

Das N, Das S, Khuntia BK and Sahu B, 2020. Effect of feed probiotic on the growth and their colonization performance on the intestine of rohu (Labeo rohita). Int J Curr Microbiol App Sci, 9(3): 806823, doi: 10.20546/ijcmas. 2020.903.095

Defoirdt T, Boon N, Bossier P and Verstraete W 2004. Disruption of bacterial quorum sensing: An unexplored strategy to fight infections in aquaculture. Aquaculture, 240(1-4): 69-88, doi: 10.1016/j.aquaculture. 2004.06.031

Dhanaraj M, Haniffa MA, Singh SA, Arockiaraj AJ, Ramakrishanan CM et al., 2010. Effect of probiotics on growth performance of koi carp (Cyprinus carpio). J Appl Aquac, 22: 202-209, doi: 10.1080/ 10454438.2010.497739

Divya KR, Isamma A, Ramasubramanian V, Sureshkumar S and Arunjith TS, 2012. Colonization of probiotic bacteria and its impact on ornamental fish Puntius conchonius. J Environ Biol, 33(3): 551-555

FAO, 2020. The State of World Fisheries and Aquaculture 2020. Sustainability in action. Rome, Italy

FAO/WHO, 2001. Report on Joint FAO/WHO Expert Consultation on Evaluation of Health and Nutritional Properties of Probiotics in Food Including Powder Milk with Live Lactic Acid Bacteria. 1-4 October, Cordoba, Argentina

Fukami K, Nishijima T and Ishida Y, 1997. Stimulative and inhibitory effects of bacteria on the growth of microalgae. Hydrobiologia, 358(1-3): 185-191, doi: 10.1023/A:1003139402315

Gatesoupe FJ, 1999. The use of probiotics in aquaculture. 
Aquaculture, 180(1-2): 147-165, doi: 10.1016/ S0044-8486(99)00187-8

Ghosh K, Sen SK and Ray AK, 2004. Growth and survival of rohu Labeo rohita (Hamilton) spawn fed diets fermented with intestinal bacterium, Bacillus circulans. Acta Ichthyol Piscat, 34(2): 155-165

Ghosh S, Sinha A and Sahu C, 2007. Effect of probiotic on reproductive performance in female live bearing ornamental fish. Aquac Res, 38: 518-526, doi: 10.1111/j.1365-2109.2007.01696.x

Ghosh S, Sinha A and Sahu C, 2008. Dietary probiotic supplementation in growth and health of livebearing ornamental fishes. Aquac Nutr, 14(4): 289299, doi: 10.1111/j.1365-2095.2007. 00529.x

Giri SS, Sen SS and Sukumaran V, 2012. Effects of dietary supplementation of potential probiotic Pseudomonas aeruginosa VSG-2 on the innate immunity and disease resistance of tropical freshwater fish, Labeo rohita. Fish Shellfish Immunol, 32(6): 1135-1140, doi: 10.1016/ j.fsi.2012.03.019

Giri SS, Sukumaran V and Oviya M, 2013. Potential probiotic Lactobacillus plantarum VSG3 improves the growth, immunity, and disease resistance of tropical freshwater fish. Fish Shellfish Immunol, 34: 660-666, doi: 10.1016/j.fsi.2012.12.008

Giri SS, Sukumaran V, Sen SS and Jena PK, 2014. Effects of dietary supplementation of potential probiotic Bacillus subtilis VSG1 singularly or in combination with Lactobacillus plantarum VSG3 or/and Pseudomonas aeruginosa VSG2 on the growth, immunity and disease resistance of Labeo rohita. Aquac Nutr, 20: 163-171, doi: 10.1111/anu. 12062

Gobi N, Malaikozhundan B, Sekar V, Shanthi S, Vaseeharan B et al., 2016. GFP tagged Vibrio parahaemolyticus Dahv2 infection and the protective effects of probiotic Bacillus licheniformis Dahb1 on the growth, immune and antioxidant responses in Pangasius hypophthalmus. Fish Shellfish Immunol, 52: 230-238, doi: 10.1016/ j.fsi.2016.03.006

Gobi N, Vaseeharan B, Chen JC, Rekha R, Vijayakumar S et al., 2018. Dietary supplementation of probiotic Bacillus licheniformis Dahb1 improves growth performance, mucus and serum immune parameters, antioxidant enzyme activity as well as resistance against Aeromonas hydrophila in Tilapia
Oreochromis mossambicus. Fish Shellfish Immunol, 74: 501-508, doi: 10.1016/j.fsi.2017.12.066

Gopalakannan A and Arul V, 2011. Inhibitory activity of probiotic Enterococcus faecium MC13 against Aeromonas hydrophila confers protection against hemorrhagic septicemia in common carp Cyprinus carpio. Aquac Int, 19(5): 973-985, doi: 10.1007/ s10499-011-9415-2

Gupta A, Gupta P and Dhawan A, 2014. Dietary supplementation of probiotics affects growth, immune response and disease resistance of Cyprinus carpio fry. Fish Shellfish Immunol, 41: 113-119, doi: 10.1016/j.fsi.2014.08.023

Gupta S, Bhathena ZP, Kumar S, Nuzaiba PM, Srivastava PP et al., 2020. Comparative efficacy of mannanoligosaccharides from two yeast species fed alone or in combination with probiotic Bacillus subtilis ATCC 6633 to Catla (Catla catla) juveniles. Aquac Int, 28(2): 691-710, doi: 10.1007/s10499-01900488-x

Hoseinifar SH, Dadar M and Ringø E, 2017. Modulation of nutrient digestibility and digestive enzyme activities in aquatic animals: the functional feed additives scenario. Aquac Res, 48(8): 3987-4000, doi: 10.1111/are.13368

Hoseinifar SH, Sun YZ, Wang A and Zhou Z, 2018. Probiotics as means of diseases control in aquaculture, a review of current knowledge and future perspectives. Front Microbial, 9: 2429 doi: 10.3389/fmicb.2018.02429

Huang Y, Zhang L, Tiu L and Wang HH, 2015. Characterization of antibiotic resistance in commensal bacteria from an aquaculture ecosystem. Front Microbial, 6: 914, doi: 10.3389/ fmicb.2015.00914

Jha DK, Bhujel RC and Anal AK, 2015. Dietary supplementation of probiotics improves survival and growth of rohu (Labeo rohita Ham.) hatchlings and fry in outdoor tanks. Aquaculture, 435: 475479, doi: 10.1016/j.aquaculture.2014.10.026

Kalarani V, Sumathi V, Roshan JK, Sowjanya D and Reddy DC, 2016. Effect of dietary supplementation of Bacillus subtilis and Terribacillus saccharophillus on innate immune responses of a tropical freshwater fish, Labeo rohita. J Clin Cell Immunol, 7: 395 
Kesarcodi-Watson A, Kaspar H, Lategan MJ and Gibson L, 2008. Probiotics in aquaculture: the need, principles and mechanisms of action and screening processes. Aquaculture, 274(1): 1-14, doi: 10.1016/ j.aquaculture.2007.11.019

Knipe H, Temperton B, Lange A, Bass D and Tyler CR, 2020. Probiotics and competitive exclusion of pathogens in shrimp aquaculture. Rev Aquac, 1-29, doi: $10.1111 /$ raq. 12477

Kumar P, Jain KK and Sardar P, 2018a. Effects of dietary synbiotic on innate immunity, antioxidant activity and disease resistance of Cirrhinus mrigala juveniles. Fish Shellfish Immunol, 80: 124-132, doi: 10.1016/j.fsi.2018.05.045

Kumar P, Jain KK, Sardar P, Jayant M and Tok NC, 2018 b. Effect of dietary synbiotic on growth performance, body composition, digestive enzyme activity and gut microbiota in Cirrhinus mrigala (Ham) fingerlings. Aquac Nutr, 24: 921-929, doi: 10.1111/ anu. 12628

Kumar R, Mukherjee SC, Prasad KP and Pal AK, 2006. Evaluation of Bacillus subtilis as a probiotic to Indian major carp Labeo rohita (Ham.). Aquac Res, 37: 1215-1221, doi: 10.1111/j.13652109.2006.01551.x

Kumar R, Mukherjee SC, Ranjan R and Nayak SK, 2008. Enhanced innate immune parameters in Labeo rohita (Ham.) following oral administration of Bacillus subtilis. Fish Shellfish Immunol, 24(2): 168-72, doi: 10.1016/j.fsi.2007.10.008

Kumar R, Mukherjee SC, Ranjan R, Vani T, Brahmachari RK et al., 2015. Effect of dietary supplementation of Bacillus subtilis on haematological and immunological parameters of Catla catla (Hamilton). Aquac Int, 23: 1275-1292, doi: 10.1007/ s10499-015-9883-x

Lakshmi B, Viswanath B and Sai Gopal DVR, 2013. Probiotics as antiviral agents in shrimp aquaculture. J Pathog, 2013: 424123, doi: 10.1155/2013/424123

Lara-Flores M and Aguirre-Guzman G, 2009. The use of probiotic in fish and shrimp aquaculture. A review. In: Probiotics: production, evaluation and uses in animal feed (Perez-Guerra N, Pastrana-Castro L, eds).
Research Signpost, Kerala, pp4-16

Lara-Flores M, 2011. The use of probiotic in aquaculture: An overview. Int Res J Microbiol, 2(12): 471-478

Lilly DM and Stillwell RH, 1965. Probiotics: growthpromoting factors produced by microorganisms. Science, 147(3659): 747-748, doi: 10.1126/ science. 147.3659 .747

Miller MM and Bassler BL, 2001. Quorum sensing in bacteria. Annu Rev Microbiol, 55: 165-199, doi: 10.1146/annurev.micro.55.1.165

Mohapatra S, Chakraborty T, Kumar V, De Boeck G and Mohanta KN, 2012a. Aquaculture and stress management: A review of probiotic intervention. J Anim Physiol Anim Nut, 97: 405-430, doi: 10.1111 / j.1439-0396. 2012.01301.x

Mohapatra S, Chakraborty T, Prusty AK, Das P, Paniprasad K et al., 2012b. Use of different microbial probiotics in the diet of rohu, Labeo rohita fingerlings: effects on growth, nutrient digestibility and retention, digestive enzyme activities and intestinal microflora. Aquac Nutr, 18: 1-11, doi: 10.1111/j.1365-2095.2011.00866.x

Mohapatra S, Chakraborty T, Prusty AK, PaniPrasad K and Mohanta KN, 2014. Beneficial effects of dietary probiotics mixture on hemato-immunology and cell apoptosis of Labeo rohita fingerlings reared at higher water temperatures. PLoS One, 9(6): e100929, doi: 10.1371/journal. pone.0100929

Moriarty DJW, 1998. Control of luminous Vibrio species in penaeid aquaculture ponds. Aquaculture, 164: 351-358, doi: 10.1016/S0044-8486(98)00199-9

Mukherjee A and Ghosh K, 2016. Antagonism against fish pathogens by cellular components and verification of probiotic properties in autochthonous bacteria isolated from the gut of an Indian major carp, Catla catla (Hamilton). Aquac Res, 47: 2243-2255, doi: 10.1111/are.12676

Mukherjee A, Chandra G and Ghosh K, 2019. Single or conjoint application of autochthonous Bacillus strains as potential probiotics: effects on growth, feed utilization, immunity and disease resistance in rohu, Labeo rohita (Hamilton). Aquaculture, 512: 734302, doi: 10.1016/j.aquaculture. 2019. 734302

Naik ATR, Murthy HS and Ramesha TJ, 1999. Effect of graded levels of G-probiotic on growth, survival 
and feed conversion of tilapia, Oreochromis mossambicus. Fish Technol, 36: 63-66

Nandi A, Banerjee G, Dan SK, Ghosh K and Ray AK, 2018. Evaluation of in vivo probiotic efficiency of Bacillus amyloliquefaciens in Labeo rohita challenged by pathogenic strain of Aeromonas hydrophila MTCC 1739. Probiotics Antimicrob Proteins, 10(2): 391-398, doi: 10.1007/s12602-0179310-x

Nayak SK, Swain P and Mukherjee SC, 2007. Effect of dietary supplementation of probiotic and vitamin $\mathrm{C}$ on the immune response of Indian major carp, Labeo rohita (Ham.). Fish Shellfish Immunol, 23: 892-896, doi: 10.1016/j.fsi.2007.02.008

Nurhajati J, Atira, Aryantha INP and Kadek IDG, 2012. The curative action of Lactobacillus plantarum FNCC 226 to Saprolegnia parasitica A3 on catfish (Pangasius hypophthalamus, Sauvage). Int Food Res J, 19(4): 1723-1727

Parthasarathy R and Ravi D, 2011 Probiotic bacteria as growth promoter and biocontrol agent against Aeromonas hydrophila in Catla catla (Hamilton, 1822). Indian J Fish, 58(3): 87-93

Rajikkannu M, Natarajan N, Santhanam P, Deivasigamani B, Ilamathi J et al., 2015. Effect of probiotics on the haematological parameters of Indian major carp (Labeo rohita). Int J Fish Aquat Stud, 2(5): 105-109

Ramesh D and Souissi S, 2018. Effects of potential probiotic Bacillus subtilis KADR1 and its subcellular components on immune responses and disease resistance in Labeo rohita. Aquac Res, 49(1): 367-377, doi: 10.1111/are.13467

Ramesh D, Souissi S and Ahamed TS, 2017. Effects of the potential probiotics Bacillus aerophilus KADR3 in inducing immunity and disease resistance in Labeo rohita. Fish Shellfish Immunol, 70: 408-415, doi: 10.1016/j.fsi.2017.09.037

Ramesh D, Vinothkanna A, Rai AK and Vignesh VS, 2015. Isolation of potential probiotic Bacillus spp. and assessment of their subcellular components to induce immune responses in Labeo rohita against
Aeromonas hydrophila. Fish Shellfish Immunol, 45(2): 268-276, doi: 10.1016/j.fsi.2015.04.018

Sangma T and Kamilya D, 2015. Dietary Bacillus subtilis FPTB13 and chitin, single or combined, modulate systemic and cutaneous mucosal immunity and resistance of catla, Catla catla (Hamilton) against edwardsiellosis. Comp Immunol Microb, 43: 8-15, doi: 10.1016/j.cimid.2015.09.003

Sankar H, Philip B, Philip R and Singh ISB, 2017. Effect of probiotics on digestive enzyme activities and growth of cichlids, Etroplus suratensis (Pearl spot) and Oreochromis mossambicus (Tilapia). Aquac Nutr, 23: 852-864, doi: 10.1111/anu.12452

Sommerset I, Krossøy B, Biering E and Frost P, 2005. Vaccines for fish in aquaculture. Expert Rev Vaccines, 1-4(1): 89-101, doi: 10.1586/ 14760584.4.1.89

Taoka Y, Maeda H, Jo JY, Jeon MJ, Bai SC et al., 2006. Growth, stress tolerance and non-specific immune response of Japanese flounder Paralichthys olivaceus to probiotics in a closed recirculating system. Fish Sci, 72(2): 310-321, doi: 10.1111/ j.1444-2906.2006.01152.x

Tinh NTN, Dierckens K, Sorgeloos P and Bossier P, 2008. A review of the functionality of probiotics in the larviculture food chain. Mar Biol, 10(1): 1-12, doi: 10.1007/s10126-007-9054-9

Van Doan H, Hoseinifar SH, Ring $\varnothing$ E, Ángeles Esteban M, Dadar M et al., 2019. Host-associated probiotics: A key factor in sustainable aquaculture. Rev Fish Sci Aquacult, 1: 16-42, doi: 10.1080/23308249. 2019.1643288

Verschuere L, Rombaut G, Sorgeloos P and Verstraete W, 2000. Probiotic bacteria as biological control agents in aquaculture. Microbiol Mol Biol R, 64(4): 655-671, doi: 10.1128/MMBR.64.4.655-671.2000

Vine NG, Leukes WD, Kaiser H, Daya S, Baxter J et al., 2004. Competition for attachment of aquaculture candidate probiotic and pathogenic bacteria on fish intestinal mucus. J Fish Dis, 27: 319-326, doi: 10.1111/j.1365-2761.2004.00542.x 